\title{
The Effect of Hypocarbia on the Cardiovascular System of Puppies
}

\author{
D. CARTWRIGHT, ${ }^{(51)}$ G. A. GREGORY, ${ }^{(52)}$ H. LOU, ${ }^{(53)}$ AND M. A. HEYMAN, ${ }^{(54)}$ \\ Departments of Anesthesia and Pediatrics and the Cardiovascular Research Institute, University of California, \\ San Francisco, California USA
}

\section{Summary}

Respiratory alkalosis (hypocapnia) is used to treat persistent pulmonary hypertension in newborns. With the exception of the brain, there are no data on the effects of hypocapnia on organ blood flow in the neonate. Therefore, we examined the effects of 2 h of hypocapnia on blood pressure, oxygen consumption, cardiac output and organ blood flows in puppies.

In six animals (group I), reducing the $\mathrm{PaCO}_{2}$ to $21.8 \pm 1.5 \mathrm{~mm}$ $\mathrm{Hg}$ (pH 7.62 \pm 0.04 ) caused an immediate and sustained reduction in cerebral blood flow (40\%) and in myocardial blood flow $(\mathbf{2 5 \%})$. There were no significant changes in arterial blood pressure, total body oxygen consumption, cardiac output, right and left ventricular rate-pressure product, or blood flow to the gut, liver, muscle, and kidneys.

In four control animals (group II) $\left(\mathrm{PaCO}_{2} 39.8 \pm 3.0\right.$, $\mathrm{pH} 7.38$ $\pm 0.04)$, there were no changes in any of the measured variables (arterial blood pressure, total body oxygen consumption, cardiac output, or blood flow to any organ, including brain and heart) during $2 \mathrm{~h}$ of normocarbic ventilation.

We did not determine whether the reductions in cerebral and myocardial blood flows were detrimental. We suspect that they were not because the animals did not develop metabolic acidosis and they had normal cardiac outputs, and ventricular rate-pressure products throughout the study.

Respiratory alkalosis is used to treat the pulmonary hypertension associated with meconium aspiration (14), infection (15), polycythemia (15), maternal indomethacin and aspirin ingestion (9), hyaline membrane disease (7), and pulmonary hypoplasia (diaphragmatic hernia) (36). Alkalosis is also used to treat idiopathic pulmonary hypertension (46). In all of these cases, it is occasionally necessary to raise the pH to $7.60\left(\mathrm{PaCO}_{2} 20 \mathrm{~mm} \mathrm{Hg}\right)$ to cause the desired reduction in pulmonary artery pressure. There is concern among clinicians that this degree of hypocapnia may alter cardiac output and its distribution.

The effects of $\mathrm{PaCO}_{2}$ on regional blood flow have been studied in adult animals but not in newborns. In the adult, hypocapnia either decreases myocardial blood flow $(32,42,45)$ or maintains it constant $(21,42,45,48)$. Gastrointestinal blood flow decreases. A similar reduction in gut blood flow in the neonate may cause necrotizing enterocolitis, an entity thought to result from hypoperfusion (30).

We felt it important to determine the effects of respiratory alkalosis $\left(\mathrm{PaCO}_{2} \sim 20 \mathrm{~mm} \mathrm{Hg}\right)$ on the regional blood flow of newborn animals before this form of therapy is widely used in human infants. To do so, we measured the cardiac output and organ blood flow of 5-10-day-old puppies before and after their $\mathrm{PaCO}_{2}$ was reduced to $21.8 \pm 1.5 \mathrm{~mm} \mathrm{Hg}$. Puppies were used for these studies because they, like human babies, are immature at birth.

\section{MATERIALS AND METHODS}

We studied 12 5-10-day-old mongrel dogs who weighed 505$855 \mathrm{~g}$. They were anesthetized with $70 \%$ nitrous oxide throughout the study and paralyzed with $0.1 \mathrm{mg} / \mathrm{kg}$ of pancuronium. Their tracheae were intubated, and their lungs were mechanically ventilated with a Harvard small animal volume ventilator. Their tracheal pressures were continuously recorded from an 18-gauge needle; the needle tip was positioned near the tracheal end of the endotracheal tube. The needle was connected by stiff pressure tubing to a Gould-Statham $823 \mathrm{DB}$ pressure transducer. The response time of the needle, catheter, and strain gauge was flat to $15.1 \mathrm{~Hz}$.

The right groin and both sides of the neck were infiltrated with $0.5 \mathrm{ml}$ of $1 \%$ xylocaine and catheters were inserted into the femoral artery and vein, left ventricle (via left carotid artery), and right ventricle (via right jugular vein). The femoral vein catheter was used to infuse $10 \%$ dextrose in 0.2 normal saline $(2-4 \mathrm{ml} / \mathrm{kg} / \mathrm{h})$, transfuse blood, and administer pancuronium bromide. The femoral artery catheter was used to monitor arterial blood pressure, blood gases, and $\mathrm{pH}$, and to withdraw blood for reference samples during microsphere injections (28). The left ventricular catheter was used to inject radionuclide-labeled microspheres. The right ventricular catheter was used to measure right ventricular pressures, and to withdraw blood for determination of mixed venous blood gases and $\mathrm{pH}$. We were unsuccessful in advancing catheters into the pulmonary arteries of these small animals so we used right ventricular systolic pressure as an index of pulmonary artery pressure.

After allowing $30 \mathrm{~min}$ for recovery from the surgical manipulations, we measured blood gases and $\mathrm{pH}$. We found them to be normal in all but two animals. These two had a small amount of metabolic acidosis which was corrected with $2 \mathrm{meq} / \mathrm{kg}$ of sodium bicarbonate. Two-tenths $\mathrm{ml}$ of blood was withdrawn from the femoral artery and from the right ventricle before each microsphere injection. With each sample, we determined $\mathrm{pH}$, $\mathrm{PO}_{2}, \mathrm{PCO}_{2}$, oxygen saturation, and hemoglobin concentration. Blood gases and $\mathrm{pH}$ were measured with a Corning 175 blood gas analyzer and corrected for body temperature and $\mathrm{pH}$. Hemoglobin concentration and oxygen saturation were determined with a Radiometer Hemoximeter. Next, microspheres were injected into the left ventricle to determine control (normocarbic) cardiac output and organ blood flow. The microspheres were injected over 20-30 sec and $5 \mathrm{ml}$ of arterial blood ("reference organ sample") were withdrawn over a 2 -min period. An equal volume of maternal blood was infused into the femoral vein during the withdrawal to maintain a constant blood volume. We injected 200,000 to $800,00015-\mu \mathrm{m}$ radionuclide microspheres during each cardiac output measurement to ensure that there was an adequate number of micropheres present to accurately determine organ blood flows (28). Because injecting the spheres did not affect the arterial blood pressure, we conclude that they did not significantly obstruct the circulation. The rectal temper- 
Table 1. Variables measured during a 2-h period of controlled ventilation*

\begin{tabular}{|c|c|c|c|}
\hline \multirow[b]{2}{*}{ Variable } & \multirow[b]{2}{*}{ Control } & \multicolumn{2}{|c|}{ During normocarbic ventilation } \\
\hline & & $15 \mathrm{~min}$ & $120 \mathrm{~min}$ \\
\hline $\begin{array}{l}\text { Arterial } \mathrm{PO}_{2}(\mathrm{~mm} \\
\mathrm{Hg})\end{array}$ & $141.5 \pm 16.2$ & $135.7 \pm 26.0$ & $132.2 \pm 18.5$ \\
\hline $\begin{array}{l}\text { Arterial oxygen } \\
\text { saturation (\%) }\end{array}$ & $100 \pm 0.0$ & $100 \pm 0.0$ & $100 \pm 0.0$ \\
\hline $\begin{array}{l}\text { Arterial } \mathrm{PCO}_{2}(\mathrm{~mm} \\
\quad \mathrm{Hg})\end{array}$ & $41.3 \pm 2.5$ & $37.7 \pm 4.9$ & $42.3 \pm 3.0$ \\
\hline Arterial $\mathrm{pH}$ & $7.34 \pm 0.03$ & $7.37 \pm 0.02$ & $7.33 \pm 0.01$ \\
\hline $\begin{array}{l}\text { Venous } \mathrm{PO}_{2}(\mathrm{~mm} \\
\mathrm{Hg})\end{array}$ & $32.5 \pm 3.5$ & $35.0 \pm 2.8$ & $41.0 \pm 2.8$ \\
\hline $\begin{array}{l}\text { Venous oxygen } \\
\text { saturation (\%) }\end{array}$ & $60.5 \pm 5.6$ & $63.1 \pm 4.2$ & $65.7 \pm 8.3$ \\
\hline $\begin{array}{l}\text { Arterial oxygen } \\
\text { content (ml/100 } \\
\text { ml) }\end{array}$ & $14.58 \pm 2.6$ & $14.56 \pm 2.1$ & $14.30 \pm 1.8$ \\
\hline $\begin{array}{l}\text { Venous oxygen } \\
\text { content }(\mathrm{ml} / 100 \\
\mathrm{ml})\end{array}$ & $8.69 \pm 1.7$ & $8.42 \pm 0.9$ & $9.13 \pm 0.4$ \\
\hline $\begin{array}{l}\text { Arterial-venous } \\
\text { oxygen content } \\
\text { difference }(\mathrm{ml} / \\
100 \mathrm{ml})\end{array}$ & $5.89 \pm 1.9$ & $6.15 \pm 1.5$ & $5.17 \pm 1.4$ \\
\hline $\begin{array}{l}\text { Oxygen consump- } \\
\text { tion }(\mathrm{ml} / \mathrm{kg} / \\
\mathrm{min})\end{array}$ & $14.94 \pm 3.7$ & $15.17 \pm 2.8$ & $13.85 \pm 1.4$ \\
\hline $\begin{array}{l}\text { Mean arterial } \\
\text { blood pressure } \\
(\mathrm{mm} \mathrm{Hg})\end{array}$ & $74.5 \pm 22.9$ & $70.3 \pm 21.6$ & $58.0 \pm 15.3$ \\
\hline $\begin{array}{l}\text { Systemic vascular } \\
\text { resistance }\end{array}$ & $523 \pm 265$ & $478 \pm 237$ & $419 \pm 169$ \\
\hline $\begin{array}{r}\text { Cardiac output } \\
(\mathrm{ml} / \mathrm{kg} / \mathrm{min})\end{array}$ & $232 \pm 60$ & $238 \pm 59$ & $227 \pm 87$ \\
\hline
\end{tabular}

${ }^{*} \mathrm{PaCO}_{2}=38-42 \mathrm{~mm} \mathrm{Hg}$. Values are means $\pm \mathrm{SD}$.

Table 2. Tissue blood flow (flow/100 g/min) during a 2-h period of controlled ventilation*

\begin{tabular}{lccc}
\hline & $\begin{array}{c}\text { Normocarbia } \\
\text { (control) }\end{array}$ & $\begin{array}{c}\text { Normocarbia } \\
(15 \mathrm{~min})\end{array}$ & $\begin{array}{c}\text { Normocarbia } \\
(120 \mathrm{~min})\end{array}$ \\
\hline Brain & $41.20 \pm 6.69$ & $34.27 \pm 9.26$ & $40.27 \pm 7.55$ \\
Heart & $124.83 \pm 13.61$ & $110.65 \pm 19.66$ & $121.7 \pm 48.18$ \\
Gut & $63.67 \pm 18.49$ & $78.03 \pm 17.51$ & $68.05 \pm 32.81$ \\
Kidney & $166.67 \pm 23.95$ & $175.05 \pm 26.71$ & $174.17 \pm 31.89$ \\
Spleen & $110.93 \pm 67.78$ & $147.1 \pm 121.61$ & $105.85 \pm 60.96$ \\
Liver & $34.75 \pm 9.64$ & $33.05 \pm 5.40$ & $33.00 \pm 15.18$ \\
Lung & $77.67 \pm 42.41$ & $63.12 \pm 32.00$ & $49.02 \pm 39.14$ \\
Lower carcass & $11.79 \pm 5.04$ & $12.56 \pm 4.86$ & $13.05 \pm 6.25$ \\
Upper carcass & $13.87 \pm 5.33$ & $13.97 \pm 4.54$ & $13.37 \pm 6.97$ \\
\hline
\end{tabular}

$* \mathrm{PaCO}_{2}=38-42$. Values are means \pm SD.

atures of the puppies were continuously monitored and maintained at $38.5 \pm 0.3^{\circ} \mathrm{C}$ (their normal body temperature) with a Servo-controlled heating lamp and a heated water blanket. The animals were covered with Saran wrap to reduce evaporative heat loss.

Eight animals (group I) were then hyperventilated to a pH of $7.62 \pm 0.04$ and $\mathrm{a} \mathrm{PaCO}_{2}$ of $21.8 \pm 1.5 \mathrm{~mm} \mathrm{Hg}$ by increasing the rate of the ventilator. Fifteen, 30, 60, and 120 min later, we determined arterial and venous blood gases, $\mathrm{pH}$, oxygen saturation, hemoglobin concentration, and cardiac output and its distribution.

Four animals (group II) were ventilated to maintain their blood gases and $\mathrm{pH}$ at normal for $2 \mathrm{~h}$. They were used to control for the effect of time on the preparation. Microspheres were also injected after $15,30,60$, and 120 min of mechanical ventilation.
Two additional animals (group III) were prepared the same way. In addition, their ductus arteriosus was ligated. These animals allowed us to determine normal bronchial blood flow in the puppy and to check for immediate recirculation of microspheres. We tested for recirculation by injecting microspheres into the left ventricle and simultaneously withdrawing blood from the right ventricle. Radioactivity in right ventricular blood would indicate that some microspheres were not trapped by the arterial microcirculation.

At completion of the study, all animals were killed with an overdose of intravenous sodium pentobarbital and their organs were removed, weighed, and ashed. The brain was divided into left and right hemispheres, cerebellum, and brain stem; the heart was divided into atria, left and right ventricles, and ventricular septum; the right and left lungs and kidneys were separated; and the spleen, stomach, small bowel, large bowel (minus its con-

Table 3. Tissue blood flow (\% of cardiac output) during a 2-h period of controlled ventilation*

\begin{tabular}{lrrr}
\hline & \multicolumn{1}{c}{$\begin{array}{c}\text { Normocarbia } \\
\text { (control) }\end{array}$} & \multicolumn{1}{c}{$\begin{array}{c}\text { Normocarbia } \\
(15 \mathrm{~min})\end{array}$} & \multicolumn{1}{c}{\begin{tabular}{c}
\multicolumn{1}{c}{ Normocarbia } \\
$(120 \mathrm{~min})$
\end{tabular}} \\
\hline Brain & $4.21 \pm 1.00$ & $3.27 \pm 0.25$ & $4.5 \pm 1.92$ \\
Heart & $4.09 \pm 0.69$ & $3.52 \pm 0.79$ & $4.13 \pm 1.85$ \\
Gut & $14.44 \pm 2.24$ & $17.10 \pm 0.62$ & $15.37 \pm 2.49$ \\
Kidney & $12.54 \pm 2.54$ & $12.89 \pm 3.42$ & $14.43 \pm 7.21$ \\
Spleen & $2.23 \pm 1.08$ & $3.03 \pm 1.90$ & $2.32 \pm 0.69$ \\
Liver & $9.55 \pm 5.28$ & $8.39 \pm 3.15$ & $8.45 \pm 3.78$ \\
Lung & $7.44 \pm 2.17$ & $5.85 \pm 2.00$ & $4.21 \pm 1.97$ \\
Lower carcass & $13.45 \pm 3.38$ & $14.11 \pm 2.38$ & $15.41 \pm 2.84$ \\
Upper carcass & $30.70 \pm 5.57$ & $30.55 \pm 2.39$ & $29.86 \pm 7.22$ \\
\hline
\end{tabular}

* $\mathrm{PaCO}_{2}=38-42 \mathrm{~mm} \mathrm{Hg}$. Values are means $\pm \mathrm{SD}$.

Table 4. Variables measured before and during hyperventilation in six newborn dogs*

\begin{tabular}{|c|c|c|c|}
\hline \multirow[b]{2}{*}{ Variable } & \multirow{2}{*}{$\begin{array}{c}\text { Before } \\
\text { hyperventilation }\end{array}$} & \multicolumn{2}{|c|}{ During hyperventilation } \\
\hline & & $15 \mathrm{~min}$ & $120 \mathrm{~min}$ \\
\hline $\begin{array}{l}\text { Arterial } \mathrm{PO}_{2}(\mathrm{~mm} \\
\mathrm{Hg})\end{array}$ & $128.3 \pm 12.2$ & $128.5 \pm 16.3$ & $146.3 \pm 12.2$ \\
\hline $\begin{array}{l}\text { Arterial oxygen satu- } \\
\text { ration }(\%)\end{array}$ & $99.1 \pm 1.3$ & $98.2 \pm 2.17$ & $98.9 \pm 1.4$ \\
\hline $\begin{array}{l}\text { Arterial } \mathrm{PCO}_{2}(\mathrm{~mm} \\
\mathrm{Hg})\end{array}$ & $38.0 \pm 4.7$ & $21.8 \pm 1.5 \dagger$ & $19.7 \pm 3.5 \dagger$ \\
\hline Arterial pH & $7.37 \pm 0.02$ & $7.62 \pm 0.04 \dagger$ & $7.59 \pm 0.05 \dagger$ \\
\hline $\begin{array}{l}\text { Venous } \mathrm{PO}_{2}(\mathrm{~mm} \\
\mathrm{Hg})\end{array}$ & $31.5 \pm 2.1$ & $24.8 \pm 4.5 \dagger$ & $24.3 \pm 2.6 \dagger$ \\
\hline $\begin{array}{l}\text { Venous oxygen satu- } \\
\text { ration (\%) }\end{array}$ & $48.1 \pm 5.6$ & $43.1 \pm 7.9$ & $40.0 \pm 8.8$ \\
\hline $\begin{array}{l}\text { Arterial oxygen con- } \\
\text { tent }(\mathrm{ml} / 100 \mathrm{ml})\end{array}$ & $12.15 \pm 2.45$ & $12.10 \pm 1.72$ & $12.95 \pm 2.14$ \\
\hline $\begin{array}{l}\text { Venous oxygen con- } \\
\text { tent }(\mathrm{ml} / 100 \mathrm{ml})\end{array}$ & $5.97 \pm 1.8$ & $5.14 \pm 0.68$ & $4.94 \pm 1.36$ \\
\hline $\begin{array}{l}\text { Arterial-venous oxy- } \\
\text { gen content differ- } \\
\text { ence }\end{array}$ & $6.19 \pm 1.74$ & $6.96 \pm 1.42$ & $8.01 \pm 1.37$ \\
\hline $\begin{array}{l}\text { Oxygen consump- } \\
\text { tion }(\mathrm{ml} / \mathrm{kg} / \mathrm{min})\end{array}$ & $16.41 \pm 6.54$ & $16.87 \pm 6.97$ & $14.57 \pm 3.48$ \\
\hline $\begin{array}{l}\text { Mean arterial blood } \\
\text { pressure }(\mathrm{mm} \mathrm{Hg})\end{array}$ & $69 \pm 18$ & $58 \pm 21$ & $54 \pm 25$ \\
\hline $\begin{array}{l}\text { Systemic vascular re- } \\
\text { sistance }\end{array}$ & $403 \pm 181$ & $360 \pm 168$ & $352 \pm 149$ \\
\hline $\begin{array}{l}\text { Cardiac output (ml/ } \\
\mathrm{kg} / \mathrm{min})\end{array}$ & $268 \pm 86$ & $248 \pm 102$ & $184 \pm 46$ \\
\hline
\end{tabular}

* Measurements made at 30 and 60 min after commencing hyperventilation are not included, but were not significantly different from those at $15 \mathrm{~min}$.

$\dagger$ Significantly different from value before hyperventilation, $P<0.001$ (mean $\pm \mathrm{SD}$ ) 


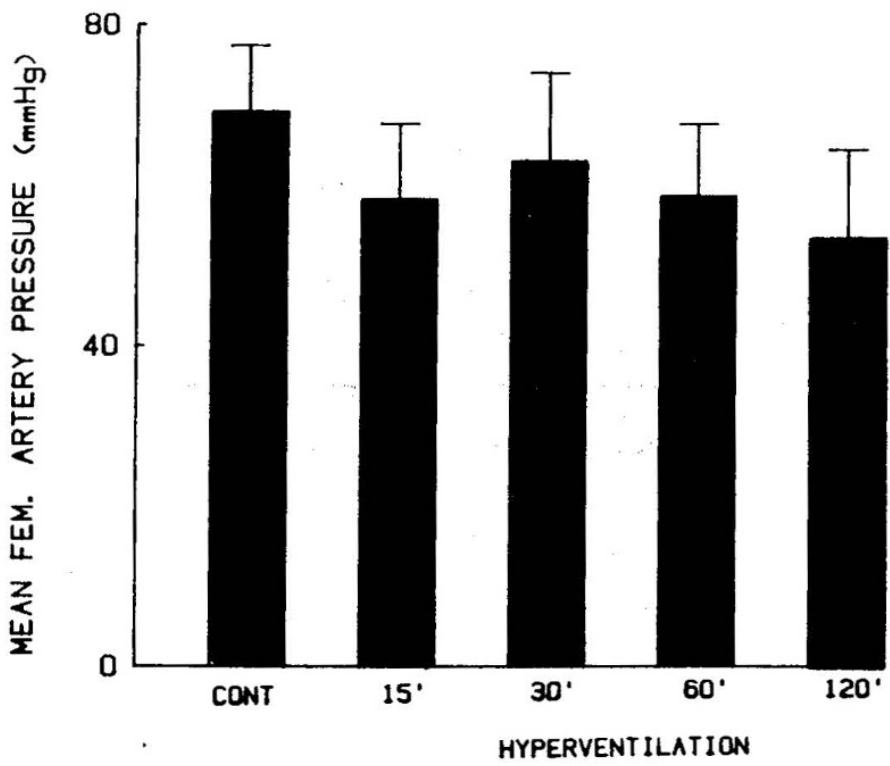

Fig. 1. The effects of respiratory alkalosis $(\mathrm{pH} 7.62 \pm 0.04)$ and time on mean arterial blood pressure. Cont, control, normal $\mathrm{PaCO}_{2}$.

Table 5. Tissue oxygen delivery $(\mathrm{ml} / \mathrm{min} / 100 \mathrm{~g}$ of tissue)*

\begin{tabular}{lcrc}
\hline & & \multicolumn{2}{c}{$\begin{array}{c}\text { During } \\
\text { hyperventilation }\end{array}$} \\
\cline { 2 - 4 } & Before & \multicolumn{1}{c}{$15 \mathrm{~min}$} & $120 \mathrm{~min}$ \\
\hline Brain & $0.73 \pm 0.21$ & $0.4 \pm 0.07$ & $0.4 \pm 0.10 \dagger$ \\
Heart & $1.12 \pm 0.4$ & $0.82 \pm 0.26$ & $0.83 \pm 0.44$ \\
Gut & $3.03 \pm 1.01$ & $3.02 \pm 0.59$ & $2.08 \pm 1.26$ \\
Kidney & $2.62 \pm 0.70$ & $2.66 \pm 0.26$ & $2.38 \pm 0.89$ \\
\hline
\end{tabular}

$*$ Values are means $\pm \mathrm{SD}$.

$\dagger P<0.01=$ different from normocarbia.

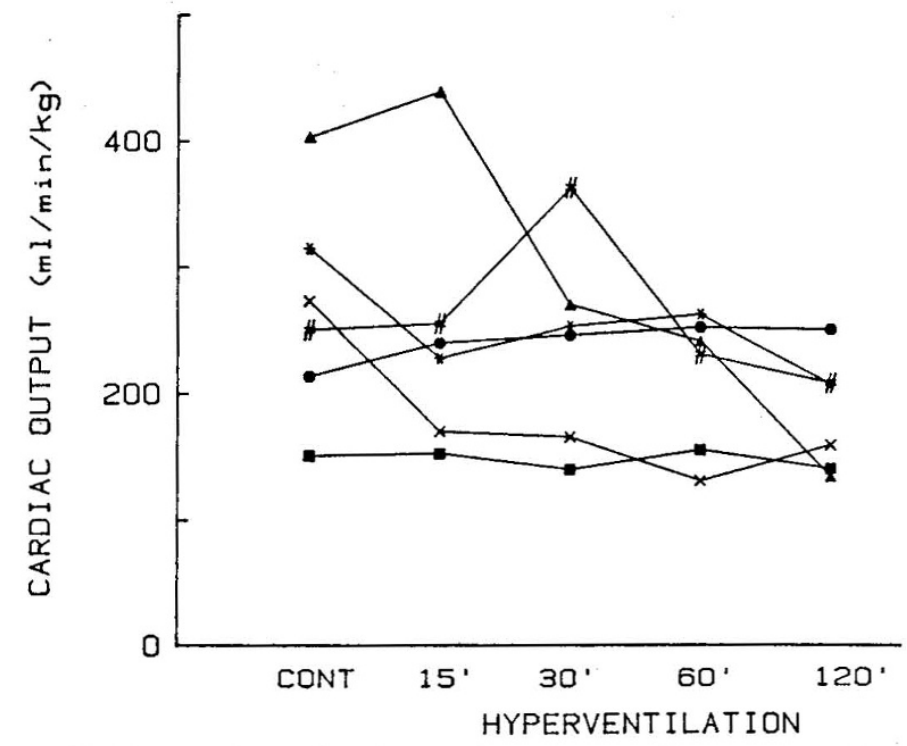

Fig. 2. The effects of respiratory alkalosis $(\mathrm{pH} 7.62 \pm 0.04)$ and time on cardiac output. Each symbol represents an individual animal. Cont, control, normal $\mathrm{PaCO}_{2}$.

tents), and liver were weighed and evaluated separately. The body of each animal was divided at the diaphragm and the two parts of the body were counted as upper and lower carcass.

Calculations and statistics. Arterial and venous oxygen contents were calculated by assuming an oxygen-hemoglobin affinity of $1.34 \mathrm{ml} \mathrm{O}_{2} / \mathrm{g}$ hemoglobin at $100 \%$ saturation. Total body oxygen uptake was calculated by multiplying the arterial-venous
Table 6. Tissue blood flow ( $\mathrm{ml} / 100 \mathrm{~g} / \mathrm{min})$ before and after the induction of hypocarbia*

\begin{tabular}{lccc}
\hline \multicolumn{1}{c}{ Organ } & Normocarbia & $\begin{array}{c}\text { Hypocarbia } \\
(15 \mathrm{~min})\end{array}$ & $\begin{array}{c}\text { Hypocarbia } \\
(120 \mathrm{~min})\end{array}$ \\
\hline Brain & $39.65 \pm 7.30$ & $21.90 \pm 3.04 \dagger$ & $18.27 \pm 2.61 \dagger$ \\
Heart & $177.47 \pm 57.45$ & $107.30 \pm 28.25 \dagger$ & $116.45 \pm 46.30 \dagger$ \\
Gut & $82.35 \pm 24.84$ & $82.05 \pm 15.57$ & $62.33 \pm 23.85$ \\
Kidney & $183.12 \pm 20.71$ & $194.07 \pm 44.60$ & $156.17 \pm 36.90$ \\
Spleen & $96.15 \pm 32.07$ & $90.47 \pm 72.90$ & $67.82 \pm 18.82$ \\
Liver & $12.09 \pm 6.63$ & $10.16 \pm 3.35$ & $17.89 \pm 7.05$ \\
Lung & $47.15 \pm 31.37$ & $30.35 \pm 22.13$ & $14.30 \pm 10.50$ \\
Lower carcass & $19.20 \pm 10.55$ & $18.78 \pm 13.89$ & $13.94 \pm 6.18$ \\
Upper carcass & $17.35 \pm 8.53$ & $16.10 \pm 9.48$ & $11.53 \pm 4.02$ \\
\hline
\end{tabular}

* $\mathrm{PaCO}_{2} 21.8 \pm 1.5 \mathrm{~mm} \mathrm{Hg}$. Values are means $\pm \mathrm{SD}$.

$\dagger P<0.001=$ different from normocarbia.

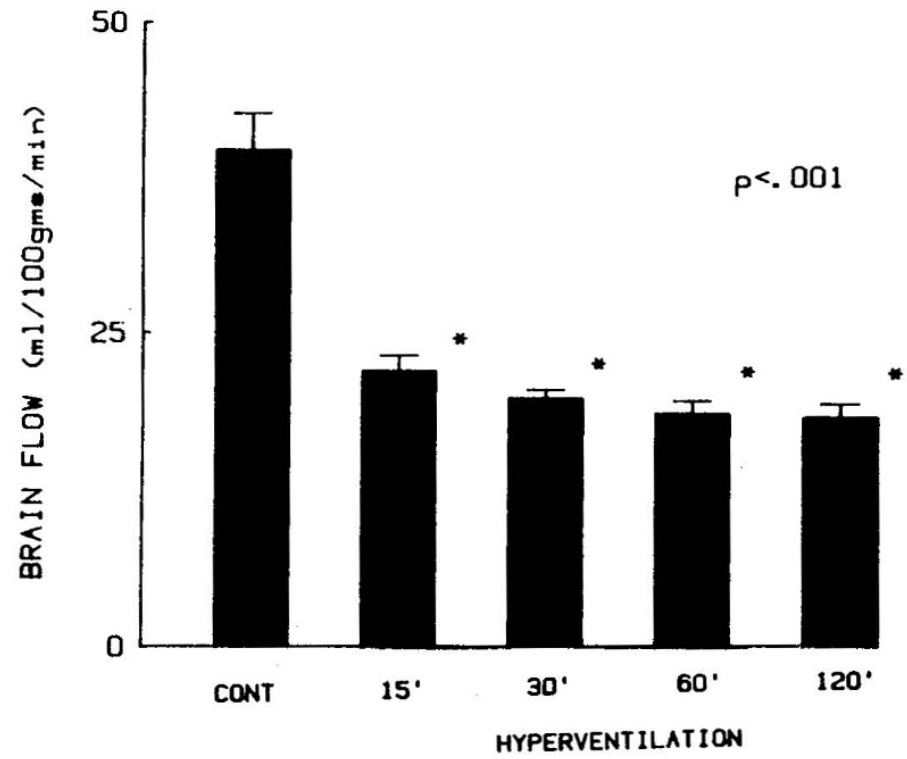

Fig. 3. The effects of respiratory alkalosis $(\mathrm{pH} 7.62 \pm 0.04)$ and time on brain blood flow. Note that alkalosis significantly reduced cerebral blood flow. Also note that it did not increase with time. Cont, control, normal $\mathrm{PaCO}_{2}$. ${ }^{*}, P<0.001=$ different from normocarbia.

oxygen content difference by cardiac output. The rate-pressure product (heart rate $\times$ peak systolic pressure) was calculated as an index of myocardial oxygen requirement (13).

The data were analyzed by one-way or two-way analysis of variance and Newman-Keuls testing. A Bonferroni correction was used. A $P$ value $<0.05$ was considered significant.

\section{RESULTS}

Two animals were excluded from the analysis, one because $50 \%$ of cardiac output entered the lung, and the other because there was unequal distribution of microspheres between left- and right-sided organs. The following data are from the remaining 12 animals (6 hyperventilated, 4 nonhyperventilated controls, 2 ductus arteriosus ligation).

On four separate determinations, the bronchial blood flow was $2.6 \pm 1.3 \%$ of the cardiac output in the two group III animals. It was arbitrarily decided to accept studies in which the blood flow to the lung was as high as $11 \%$ of the cardiac output as representing an acceptably small left-to-right shunt through the ductus arteriosus. There was no evidence of recirculation of microspheres.

Ventilation and hemodynamic changes. The ventilator rate of groups I and II was $32 \pm 1.6$ (SD) breaths/min during the control period. The peak airway pressure was $6.6 \pm 0.5 \mathrm{~mm} \mathrm{Hg}$ and the end expiratory pressure was $0 \mathrm{~mm} \mathrm{Hg}$. Hyperventilation was 
easily accomplished in group II by increasing the ventilator rate to $78.2 \pm 4.9$ breaths/min while maintaining a constant tidal volume. This resulted in a peak airway pressure of $10 \pm 1.5 \mathrm{~mm}$ $\mathrm{Hg}$ and an end expiratory pressure of zero. The desired $\mathrm{PaCO}_{2}$ and $\mathrm{pH}$ were easily achieved and maintained throughout the experiments.

In group I, there were no significant changes in any of the measured or calculated variables, including cardiac output and organ blood flows (Tables 1-3). Intravascular pressures remained within normal limits.

In group II, there were no significant changes in hemoglobin concentration, arterial oxygen tension, saturation, or content, venous oxygen saturation or content, or arteriovenous oxygen content difference, although there was a tendency for the venous oxygen content to fall and the arteriovenous oxygen difference to increase (Table 4). There was significant difference in venous $\mathrm{PO}_{2}$ between the control and the hyperventilated states in group II, due to the Bohr effect (4). This resulted in a lower $\mathrm{PO}_{2}$ at the same oxygen saturation.

There was no significant change in mean arterial blood pressure (Fig. 1) in group II, although it fell from 80 to $35 \mathrm{~mm} \mathrm{Hg}$ in one animal due to a marked reduction in systemic vascular resistance. This fall occurred with the onset of hyperventilation and remained constant thereafter. In two other animals, the mean arterial pressure fell $15-20 \%$ during the last hour of the study. On average, there was no change in the systemic vascular resistance during the study period (Table 4). There was also no change in either the right or the left ventricular rate-pressure products.

Oxygen consumption and delivery. There was no significant change in group II in total body oxygen consumption (Table 4) or in oxygen delivery (tissue blood flow $x$ oxygen content of arterial blood) (Table 5) to any organ except the brain in group II. Oxygen delivery to the brain was reduced $46 \%$ by hypocarbia and remained constant throughout the remainder of the study.

Cardiac output and organ blood flows. Hyperventilation had no significant effect on cardiac output (Fig. 2). There was, however, a tendency for it to decrease $20-30 \%$ in some animals after $2 \mathrm{~h}$ of hyperventilation. This did not occur in the control animals (Table 1).

Only the brain and heart showed a significant change in blood flow $/ \mathrm{min} / 100 \mathrm{~g}$ during hyperventilation. Cerebral blood flow was decreased $40 \%(39.7 \pm 7.3$ to $21.9 \pm 3.03 \mathrm{ml} / \mathrm{min} / 100 \mathrm{~g})(P$ $<0.01$ ) by hyperventilation (Table 6 and Fig. 3). This reduction

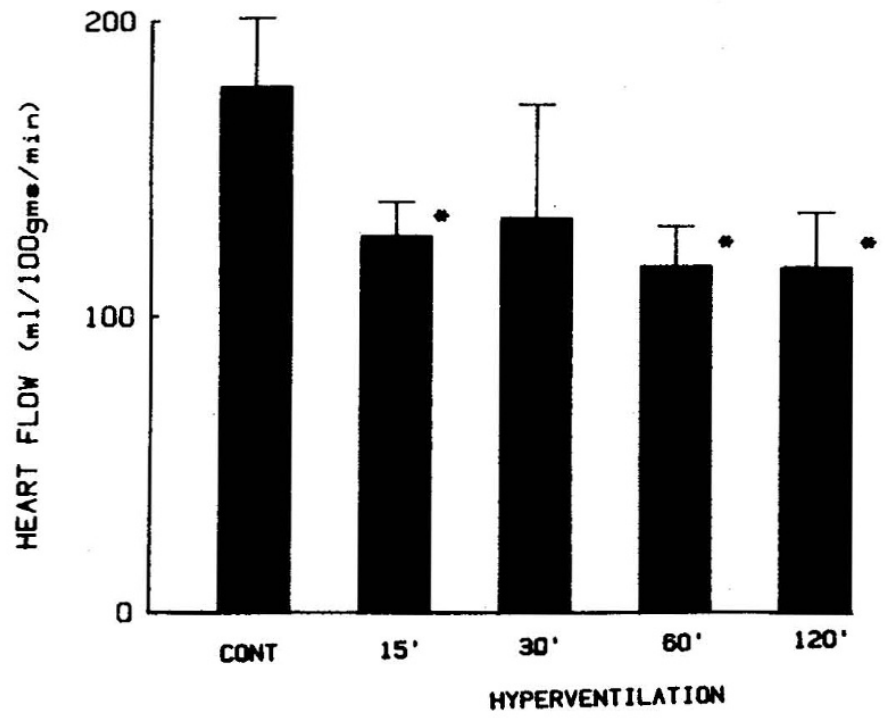

Fig. 4. The effects of respiratory alkalosis $(\mathrm{pH} 7.62 \pm 0.04)$ and time on cardiac blood flow. Blood flow was significantly reduced by alkalosis. Flow did not increase with time. Cont, control, normal $\mathrm{PaCO}_{2} .{ }^{*}, P<$ $0.01=$ different from normocarbia.

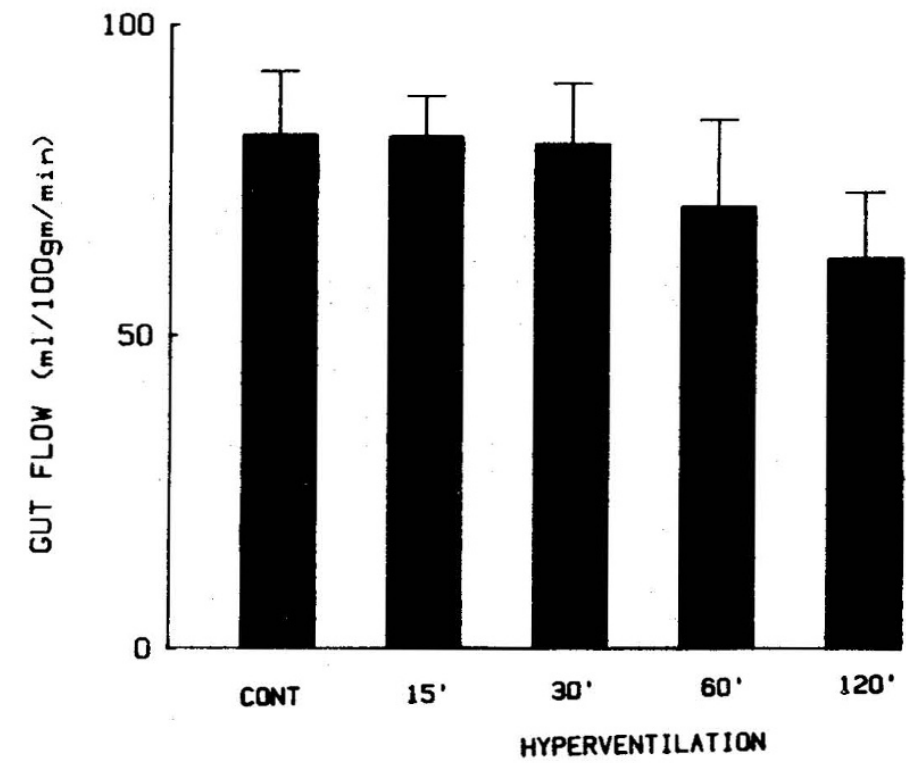

Fig. 5. The effects of respiratory alkalosis ( $\mathrm{pH} 7.62 \pm 0.04)$ and time on gut blood flow. Cont, control, normal $\mathrm{PaCO}_{2}$.

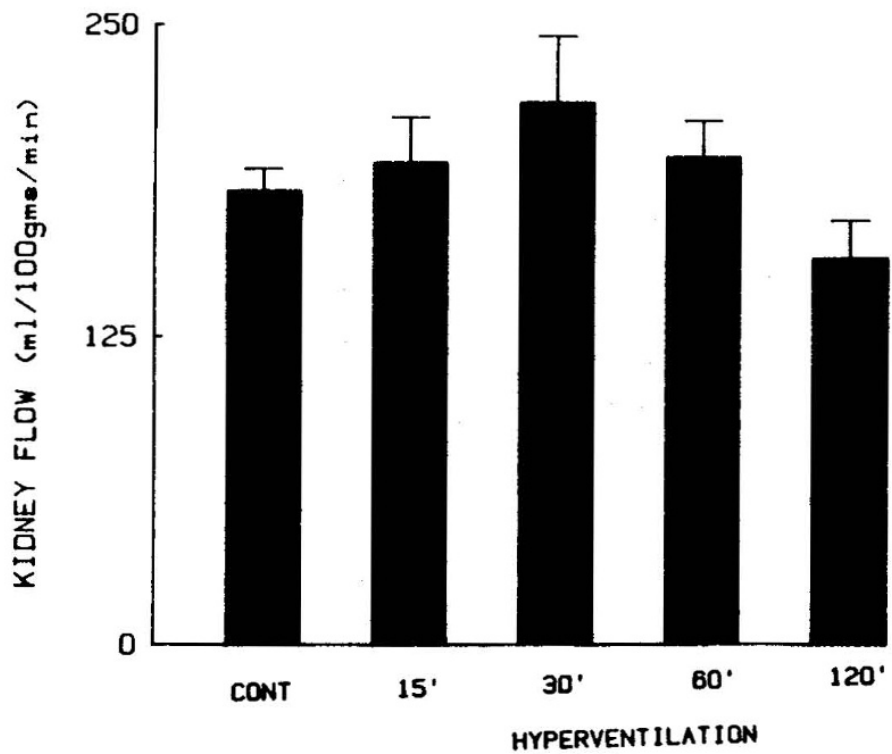

Fig. 6. The effects of respiratory alkalosis $(\mathrm{pH} 7.62 \pm 0.04)$ on kidney blood flow. Cont, control, normal $\mathrm{PaCO}_{2}$.

Table 7. Tissue blood flow (\% cardiac output) before and after the induction of hypocarbia*

\begin{tabular}{lrrr}
\hline \multicolumn{1}{c}{ Organ } & Normocarbia & $\begin{array}{c}\text { Hypocarbia } \\
(15 \mathrm{~min})\end{array}$ & \multicolumn{1}{c}{$\begin{array}{c}\text { Hypocarbia } \\
(120 \mathrm{~min})\end{array}$} \\
\hline Brain & $3.61 \pm 1.11$ & $2.18 \pm 0.54$ & $2.39 \pm 0.64$ \\
Heart & $5.39 \pm 1.07$ & $4.51 \pm 1.59$ & $5.29 \pm 1.29$ \\
Gut & $14.55 \pm 2.24$ & $16.45 \pm 3.12$ & $14.07 \pm 3.11$ \\
Kidney & $13.07 \pm 4.01$ & $14.63 \pm 2.80$ & $15.89 \pm 5.81$ \\
Spleen & $2.04 \pm 0.60$ & $2.01 \pm 1.57$ & $2.07 \pm 1.10$ \\
Liver & $3.16 \pm 2.26$ & $2.91 \pm 1.62$ & $6.16 \pm 3.41$ \\
Lung & $5.80 \pm 3.50$ & $4.02 \pm 2.16$ & $2.99 \pm 1.90$ \\
Lower carcass & $19.15 \pm 5.28$ & $19.80 \pm 5.21$ & $18.73 \pm 4.03$ \\
Upper carcass & $31.85 \pm 5.30$ & $32.00 \pm 4.83$ & $31.80 \pm 5.50$ \\
\hline${ }^{*}$ Paco 2 21.8 $\pm 1.5 \mathrm{~mm} \mathrm{Hg}$. Values are means $\pm \mathrm{SD}$.
\end{tabular}

in flow occurred within $15 \mathrm{~min}$ of the onset of hyperventilation and persisted throughout the remainder of the study. Blood flow to the right and left cerebral hemispheres and the various areas of the brain were similar whether or not the left carotid artery was ligated during insertion of the left ventricular catheter. 
Myocardial blood flow decreased $25-40 \%(27.8 \pm 23.8)$ within 15 min of initiating hyperventilation $(P<0.01)$ (Fig. 4$)$, and remained constant thereafter. The decrease in flow was equal in all parts of the heart.

Gastrointestinal blood flow was not significantly altered by hyperventilation, but there was a tendency for it and the cardiac output to decrease during the last hour of the study (Fig. 5). All parts of the gastrointestinal tract responded similarly to hyperventilation. Liver, kidney (Fig. 6), spleen, and carcass blood flow were also unaffected by hyperventilation. There was no change in the percentage of cardiac output distributed to any of the organs, including that to heart and brain (Table 7).

\section{DISCUSSION}

We induced hyperventilation in group II by increasing the ventilator rate. It might be argued that we should have hyperventilated both groups I and II initially and then added enough $\mathrm{CO}_{2}$ to the inspired gas to maintain a normal $\mathrm{PaCO}_{2}$. This would have allowed us to withdraw the added $\mathrm{CO}_{2}$ in group II to produce alkalosis without altering the ventilator settings. We did not do this for two reasons: 1) because we had difficulty maintaining a constant $\mathrm{PaCO}_{2}$ when we attempted to add $\mathrm{CO}_{2}$ to the inspired gas, 2) because it is unknown what effect a previous period of hyperventilation has on the cardiovascular system when it is followed by a period of normocarbia. A recent study suggests that the effect on the brain may be significant (24).

The initial resting myocardial blood flow differed in both groups I and II. It was $124 \pm 13.6 \mathrm{ml} / 100 \mathrm{~g} / \mathrm{min}$ in group I and $178 \pm 56 \mathrm{ml} / 100 \mathrm{~g} / \mathrm{min}$ in group II. Cardiac output, oxygen consumption, and the arteriovenous oxygen difference were slightly greater in group II. The venous oxygen saturation and arterial $\mathrm{pH}$ were also higher in group II. Systemic vascular resistance and mean arterial pressure were lower in group II. There was no difference in the body weight, environmental or body temperatures, or the time of year the studies were done. Except for myocardial blood flow, the differences between the two groups were not significantly different by unpaired $t$ test. The initial values for myocardial flow in group I were 104-134 $\mathrm{ml} / 100 \mathrm{~g} / \mathrm{min}$. Those for group II were 116 to $273 \mathrm{ml} / 100 \mathrm{~g} /$ min. In group II, myocardial blood flow decreased when the initial flow exceeded $190 \mathrm{ml} / 100 \mathrm{~g} / \mathrm{min}$. It did not change when the initial flow was less than $150 \mathrm{ml} / 100 \mathrm{~g} / \mathrm{min}$. Five of six animals in group II had initial myocardial flows that were greater than those in group I. It is not clear why these differences existed. After the initial decrease in myocardial blood flow, the flows were similar in both groups. Reductions in myocardial blood flow similar to those found in group II have been reported in adults $(42,45)$. While the cause(s) are unknown, they might be related to a decrease in ionized calcium, tissue catecholamine levels, or myocardial oxygen consumption. We did not measure these variables in this study. Despite the decrease in myocardial blood flow, it does not appear that oxygenation of the heart was impaired because the rate-pressure-product of both ventricles [an indication of myocardial oxygen consumption (13)] remained normal and constant. The myocardial oxygen consumption of adults is unchanged (42) or increased (47) by hyperventilation. In adult dogs, myocardial oxygen consumption is decreased by hyperventilation (44). This does not appear to be detrimental because the phosphorylated nucleotide content of the heart remains constant (45).

The cardiac output of adult animals $(21,32)$ and humans $(16$, $29,41,42$ ) is either unchanged or decreased by hypocarbia. The systemic vascular resistance and blood pressure often decrease for the first 1-7 $\mathrm{min}$ of hyperventilation and then return to control levels $(16,40)$. In our animals, neither cardiac output nor peripheral vascular resistance changed significantly.

Respiratory alkalosis reduces the cerebral blood flow of neonates and adults $(22,23,27,37,49)$. The relationship between $\mathrm{PaCO}_{2}$ and cerebral blood flow is linear when the $\mathrm{PaCO}_{2}$ is between
20 and $80 \mathrm{~mm} \mathrm{Hg}(22,37,43)$. The absolute level of cerebral blood flow and the flow/100 $\mathrm{g}$ of brain are both lower in newborns than in adults of the same species $(8,22,35,37)$. The changes in cerebral blood flow per $\mathrm{mm} \mathrm{Hg}$ change in $\mathrm{PaCO}_{2}$ are either smaller $(27,37,43)$ or larger (30) than they are in adults.

This study confirms previous observations in adults $(8,40,43$, 49 ) and neonates $(37,43)$ that cerebral blood flow is reduced by hyperventilation. Unlike adults, there was no tendency for cerebral blood flow to return to normal with time. There is disagreement about whether the reduction in cerebral blood flow and oxygen delivery caused by hypocarbia is harmful. Cerebral cortical $\mathrm{PO}_{2}$ decreases when adults are hyperventilated $(2,3)$. The dominant frequency of the electroencephalograph decreases $(2$, $33,38,39$ ) when the $\mathrm{PaCO}_{2}$ is less than $20 \mathrm{~mm} \mathrm{Hg}$. This slowing can be reversed by administering $100 \%$ oxygen at $3 \mathrm{~atm}$ pressure (37). Newborn lambs and adult humans $(1,10,24,33,39)$ maintain constant cerebral metabolic rates for oxygen and glucose at $\mathrm{PaCO}_{2}$ values of $20-25 \mathrm{~mm} \mathrm{Hg}$ (23). The high energy phosphates in the brains of adult rats and cats remain normal until their $\mathrm{PaCO}_{2}$ is below $12 \mathrm{~mm} \mathrm{Hg}(10,17-19,25)$, suggesting normal citric acid cycle activity above this $\mathrm{PaCO}_{2}$. Both lines of evidence (normal cerebral metabolic rates for oxygen and glucose and normal levels of high energy phosphate) suggest that hypoxicischemic brain damage is unlikely to occur at the levels of hypocarbia used in our study $\left(\mathrm{PaCO}_{2}\right.$ of $\left.20-25 \mathrm{~mm} \mathrm{Hg}\right)$.

The increased concentration of lactate in the brains of hypocapnic adults $(3,17,19,20,25)$ is probably the result of increased glycolytic activity (10), which is due in turn to increased phosphofructokinase acitvity (17). In 1-5-day-old lambs, the increased cerebrospinal fluid lactate concentration is caused in part by the uptake of lactate from arterial blood (23). It appears that lactate provides an additional source of energy during hyperventilation, as it does in 1-3-week-old hypoglycemic puppies (44).

Since it was easy to produce respiratory alkalosis without causing high airway pressures, it is unlikely that changes in intrathoracic pressure contributed significantly to changes in myocardial and cerebral perfusion, especially since blood flow to other organs was not affected.

Previous reports indicate that hyperventilation has no effect $(16,42,47)$ on or increases total body oxygen consumption of adults. Hyperventilation had no effect on the oxygen consumption of our neonatal lambs.

Long-term follow-up of hyperventilated infants is not extensive. The outcome of such infants is variable. Most are normal (5); however, some have severe neurological handicaps (46). It is unknown whether the poor outcome of some infants is the result of the primary disease or of the hyperventilation.

\section{REFERENCES AND NOTES}

1. Alberti E, Hoyer S, Hamer J, Stoekel H, Packschiess P, Weinhardt F 1975 The effect of carbon dioxide on cerebral blood flow and cerebral metabolism in dogs. Br J Anaesthiol 7:941

2. Alexander SC, Cohen PH, Wollman H, Smitt TC, Reivich M, Van der Molen RA 1965 Cerebral carbohydrate metabolism during hypocarbia in man. Anesthesiology 26:624

3. Betz E, Pickerodt V, Weidner A 1968 Respiratory alkalosis: effect on CBF, $\mathrm{PO}_{2}$, and acid/base relations in cerebral cortex with a note on water content. Scand J Lab Clin Invest Suppl 102:IVD

4. Bohr C, Hasselbalch KA, Krogh A 1904 Ueber einen in biologischer Beziehung Wichtigen Einfluss, den die Kohlensaurespannung des blut auf dessen souerstoffbindung ubt. Scand Ach Physiol 16:402

5. Brett C, Dekle M, Leonard CH, Clark C, Sniderman S, Roth R, Ballard R, Clyman RI 1981 Developmental follow-up of hyperventilated neonates: preliminary observations. Pediatrics 68:588

6. Cain SM 1970 Increased oxygen uptake with passive hyperventilation of dogs. J Appl Physiol 28:4

7. Chu J, Clements JA, Catton EK, Klaus MH, Sweet AY, Tooley WH 1967 Neonatal pulmonary ischemia. Pediatrics 40:709

8. Cohen PJ, Alexander SC, Wollman H 1968 Effects of hypocarbia and of hypoxia with normocarbia on cerebral blood flow and metabolism in man. Scand J Lab Clin Invest Suppl 102:IVA

9. Csaba IF, Sulyok E, Ertl T 1978 Relationship of maternal treatment with indomethacin to persistence of fetal circulation syndrome. J Pediatr 92:484

10. Domonkos J,. Huszak I 1959 Effect of hydrogen-ion concentration on the carbohydrate metabolism of brain tissue. J Neurochem 4:238 
11. Drummond WH, Gregory GA, Heymann MA, Phibbs RH 1981 The independent effects of hyperventilation, tolazoline, and dopamine on infants with persistent pulmonary hypertension. J Pediatr 98:603

12. Drummond WH, Resnick MB, Keil EA, Williams BJ, Eitzman DV 1981 Follow-up evaluation of neonates treated with drugs and hyperventilation for severe persistent pulmonary hypertension. Pediatr Res 15:447

13. Fisher DJ, Heymann MA, Rudolph AM 1981 Myocardial consumption of oxygen and carbohydrates in newborn sheep. Pediatr Res 15:843

14. Fox WW, Gewitz MH, Dinwiddie R, Drummond WH, Peckham GJ 1977 Pulmonary hypertension in the aspiration syndromes. Pediatrics 59:205

15. Gersony WM 1973 Persistence of the fetal circulation: a commentary. J Pediatr 82:1103

16. Gleason WL, Berry JN, Mauney FM, McIntosh HD 1958 The hemodynamic effects of hyperventilation. Clin Res 6:127 (abstr)

17. Granholm L, Lukjanova L, Siesjo BK 1968 Evidence of cerebral hypoxia in pronounced hyperventilation. Scand J Lab Clin Invest Suppl 102-IVC

18. Granholm L, Lukjanova L, Siesjo B 1969 The effect of marked hyperventilaton upon tissue levels of NADH, lactate, pyruvate, phosphocreatine, and adenosine phosphates of rat brain. Acta Physiol Scand 77:179

19. Granholm L, Siesjo BK 1971 The effect of combined respiratory and nonrespiratory alkalosis on energy metabolites and acid-base parameters in the rat brain. Acta Physiol Scand 81:307

20. Granholm L, Siesjo BK 1969 The effects of hypercapnia and hypocapnia upon the cerebrospinal fluid lactate and pyruvate concentrations and upon the lactate, pyruvate, ATP, ADP, phosphocreatine and creatine concentrations of cat brain tissue. Acta Physiol Scand 75:257

21. Greenberg AG, Kittle CF 1968 The effects of acute changes in acid-base status on coronary blood flow. Surgery $64: 315$

22. Gregoire NM, Gjedde A, Plum F, Duffy TE 1978 Cerebral flow and cerebral metabolic rates for oxygen, glucose and ketone bodies in newborn dogs. $\mathrm{J}$ Neurochem 30:63

23. Gregory GA, Ong W, Tweed A, Wade JG 1982 The effects of severe alkalosis and hypoxemia on cerebral metabolism in the newborn lamb. Anesthesiology 57:A429

24. Gregory GA, Ong W, Tweed WA 1983 Hyperventilation restores autoregulation of the cerebral circulation of the neonate. Anesthesiology 59:A427

25. Grote J, Zimmer K, Schubert R 1981 Effects of severe arterial hypocapnia on regional blood flow regulation tissue $\mathrm{PO}_{2}$ and metabolism in the brain cortex of cats. Pflugers Arch 391:195

26. Hellman J, Vannucci RC, Nardis EE 1982 Blood brain barrier permeability to lactic acid in the newborn dog: lactate as a metabolic fuel. Pediatr Res 16:40

27. Hernandez MJ, Brennan RW, Vannucci RC, Bowman GS 1978 Cerebra blood flow and oxygen consumption in the newborn dog. Am J Physiol 234:R209

28. Heymann MA, Payne BD, Hoffman JIE, Rudolph AM 1977 Blood flow measurements with radionuclide labeled particles. Prog Cardiovasc Dis 20:55

29. Kety SS, Schmidt CF 1946 The effects of active and passive hyperventilation on cerebral blood flow, cerebral oxygen consumption cardiac output, and blood pressure of normal young men. J Clin Invest 25:107

30. Kitterman JA 1975 Necrotizing enterocolitis in the newborn infant. In: Moore TD (ed): Report of the Sixty-Eighth Conference on Pediatric Research. Columbus, $\mathrm{OH}$, Ross Laboratories, $\mathrm{p} 38$

31. Lahey FAN, Cates D, MacCallum M, Rigatto $\mathrm{H} 1980$ Effects of $\mathrm{CO}_{2}$ and $100 \% \mathrm{O}_{2}$ on cerebral blood flow in preterm infants. J Appl Physiol Resp Environ Physiol 48:468

32. Marshall M, Williams WG, Creighton RE, Volgyesi GA, Steward DJ 1976 A technique for measuring regional myocardial blood flow and its application in determining the effects of hyperventilation and halothane. Can Anaesth Soc J 23:244
33. Meyer JF, Gotoh F 1960 Metabolic and electroencephalographic effects of hyperventilation. Arch Neurol 5: 539

34. Mohamed MS, Bean JW 1967 Local and general alterations of blood $\mathrm{CO}_{2}$ and influence of intestinal motility in regulation of intestinal blood flow. Am J Physiol 21:163

35. Moore TJ, Lione AP, Regan DM, Tarpley HL, Raines PL 1971 Brain glucose metabolism in the newborn rat. Am J Physiol 221:1746

36. Naeye RL, Schochat SL, Whitman V, Maisels MJ 1976 Unsuspected pulmonary vascular abnormalities associated with diaphragmatic hernia. Pediatrics 58:902

37. Reivich M, Brann AW, Shapiro H, Rawson J, Sano N 1971 Reactivity of cerebral vessels to $\mathrm{CO}_{2}$ in the newborn rhesus monkey. Eur Neurol 6:132

38. Reivich M, Cohen PJ, Greenbaum L 1966 Alterations in the electroencephalogram of awake man produced by hyperventilation: effects of $100 \%$ oxygen at 3 atmosphere (absolute) pressure. Neurology 16:304 (abstr)

39. Reivich M, Dickson J, Clark J, Hedden M, Lambertsen CJ 1968 Role of hypoxia in cerebral circulatory and metabolic changes during hypocarbia in man: studies in hyperbaric milieu. Scand J Lab Clin Invest Suppl 102:IVB

40. Reivich M 1964 Arterial $\mathrm{PCO}_{2}$ and cerebral hemodynamics. Am J Physio 206:25

41. Richardson DW, Kontos HA, Raper AJ, Patterson JL 1972 Systemic circula tory responses to hypocapnia in man. Am J Physiol 223:1308

42. Rowe GG, Castillo CA, Crumpton CW 1962 Effects of hyperventilation on systemic and coronary hemodynamics. Am Heart J 63:67

43. Shapiro HM, Greenberg JH, Naughton KV, Reivich M 1977 Local cerebral blood flow sensitivity to carbon dioxide in newborn and adult dogs. Acta Neurol Scand (Suppl 56) 64:426 (abstr)

44. Sheuer J, Berry MN 1967 Effect of alkalosis on glycolysis in the isolated rat heart. Am J Physiol 213:1143

45. Sheuer J 1968 The effects of respiratory and metabolic alkalosis on coronary flow, hemodynamics and myocardial carbohydrate metabolism. Cardiologia $52: 275$

46. Siassi B, Goldberg SJ, Emmanouilides GC, Higashino SM, Lewis E 1971 Persistent pulmonary vascular obstruction in newborn infants. J Pediat 78:610

47. Theye RA, Gronert GA, Heffron JA 1977 Oxygen uptake of canine whole body and hind lamb with hypocapnic alkalosis. Anesthesiology 47:416

48. Wilson JR, Goldberg S, Hirshfeld JW, Hanken AH 1981 Effects of respiratory alkalosis on coronary vascular dynamics and myocardial energetics in patients with coronary artery disease. Am Heart J 102:202

49. Wollman H, Smith TC, Stephen GW, Colton ET, Gleaton HE, Alexander SC 1968 Effects of extremes of respiratory and metabolic alkalosis on cerebral blood flow in man. J Appl Physiol 23:60

50. This research was supported by Grant HL 24056 from the National Institutes of Health.

51. Research Fellow, Cardiovascular Research Institute, University of California, San Francisco, CA 94143. Supported in part by a grant from the Francis S. North Foundation. Present address: Senior Neonatology Registrar, Royal Women's Hospital, Brisbane, Q4029, Australia.

52. Professor of Anesthesia and Pediatrics, University of California, San Francisco, CA 94143. To whom reprint requests should be addressed.

53. Visiting Scientist, Department of Pediatrics and the Cardiovascular Research Institute, University of California, San Francisco, CA 94143. Supported by the Danish Medical Research Council.

54. Professor of Pediatrics, Physiology, Obstetrics, Gynecology, and Reproductive Sciences; senior staff member, Cardiovascular Research Institute, University of California, San Francisco, CA 94143.

55. Received for publication June 4, 1983

56. Accepted for publication October 13, 1983 